Iga WIERZBICKA-TUTKA'

Grzegorz SOKOKOWSKI'

Agata BAŁDYS-WALIGORSKA ${ }^{2}$

Dariusz ADAMEK ${ }^{3}$

Edyta RADWAÑSKA ${ }^{3}$

Filip GOŁKOWSKI ${ }^{2}$

'Department of Gastroenterology, Hepatology and Infectious Disease, Jagiellonian University Medical College, Kraków, Poland Head:

Prof. dr hab. Tomasz Mach

${ }^{2}$ Department of Endocrinology, Jagiellonian University Medical College, Kraków, Poland Head:

Prof. dr hab. Alicja Hubalewska-Dydejczyk

${ }^{3}$ Department of Pathology, Jagiellonian University Medical College, Kraków, Poland Head:

Dr hab. Dariusz Adamek, prof. UJ

Additional key words:

pituitary adenoma

Ki-67

PTTG

Dodatkowe słowa kluczowe:

gruczolak przysadki

$\mathrm{Ki}-67$

PTTG

This work was supported by Collegium Medicum of the Jagiellonian University Medical College statutory grants No K/ZDS/002324.

Adres do korespondencji:

Iga Wierzbicka-Tutka

Department of Gastroenterology and

Hepatology, Uniwersity Hospital in Kraków

Śniadeckich 5, 31-501 Kraków, Polska

phone: 124247340 , fax: 124247380

mobile: 607603275

e-mail: igawierzbicka@gmail.com

\title{
PTTG and Ki-67 expression in pituitary adenomas
}

\author{
Ekspresja PTT i Pij-67 w gruczolakach przysadki
}

Introduction: The unpredictable biology of pituitary adenomas makes it a therapeutic challenge. Moreover, histopathology of pituitary carcinomas and locally invasive adenomas are indistinguishable from benign tumors and a new marker which would enable to differentiate those lesions is vital. The aim of the study was to evaluate Ki-67 and PTTG (pituitary tumour-transforming gene) expression in pituitary adenomas and their application as markers of tumour aggressiveness.

Material and methods: A retrospective analysis of 55 patients: 32 females $(58 \%)$ and 23 males (42\%), mean age $50 \pm 16$ years who underwent pituitary tumor surgery between 2003-2012. Ki67 and PTTG indices were determined by immunohistochemical staining. Magnetic resonance imaging or computed tomography was performed beforehand and one year after surgery to figure a potential tumour progression, tumour size and correlation to adjacent tissues.

Results: The expression of $\mathrm{Ki}-67$ and PTTG was revealed in cell nuclei in $88 \%$ and $85 \%$ of adenomas, respectively. The median Ki-67 and PTTG indices were 1.4 and 1.0, respectively $(p=0.006)$. In the group with macroadenoma as compared with the group with microadenoma, median $\mathrm{Ki}-67$ index was higher $(1.4 \%$ vs. $1.03 \% ; p=0.02)$. We did not find correlation between both $\mathrm{Ki}-67$ and PTTG indices and tumour progression. Tumours with positive immunostaining towards FSH revealed lower Ki-67 and PTTG indices than the rest with a negative one $(0.6 \%$ vs. $1.84 \%, p=0.0004$ and $0.67 \%$ vs $1.23 \%$, $p=0.047$; respectively). However, PTTG index was higher in the group with acromegaly as compared to the group with clinically non-functioning pituitary adenoma (NFPA) $(1.28 \%$ vs. $0.35 \% ; p=0.02$ ).

Conclusions: Positive nuclear expression of Ki-67 and PTTG was observed in the majority of pituitary adenomas. Only higher Ki-67 expression was related to the tumour invasiveness found on MRI/CT. Tumour progression was not related to both $\mathrm{Ki}-67$ and PTTG expression.
Wstęp: W praktyce klinicznej zarówno przewidywanie zachowania gruczolaków przysadki jak ich leczenie jest dużym wyzwaniem. Co więcej, badanie histopatologiczne nie pozwala odróżnić raka przysadki, miejscowo naciekającego gruczolaka od zmiany ragodnej. Celem pracy była ocena ekspresji Ki-67 oraz PTTG (pituitary tumour transforming gene) w guzach przysadki i ich znaczenia jako markerów agresywności tych gruczolaków.

Material i metody: Badanie miało charakter retrospektywny. Objęło 55 badanych pacjentów: 32 kobiety $(58 \%)$ i 23 mężczyzn (42\%), średnia wieku $50 \pm 16$ lat; po operacji neurochirurgicznej z powodu gruczolaka przysadki pomiędzy 2003 a 2012 rokiem. W oparciu o badanie immunohistochemiczne preparatów obliczono indeksy Ki-67 i PTTG. Celem oceny wielkości guza, wzajemnej zależności z sąsiadującymi tkankami oraz ewentualnej wznowy, wykonano rezonans magnetyczny lub tomografię komputerowa przysadki przed i 1 rok po zabiegu.

Wyniki: Wykazano jądrowa ekspresję w komórkach gruczolaka przysadki w przypadku Ki-67 u 88\% i PTTG u $85 \%$. Mediany indeksu Ki-67 i PTTG wynosity odpowiednio $1,4 \%$ i $1,0 \%$ ( $p=0,006)$. W grupie $z$ makrogruczolakiem, indeks $\mathrm{Ki}$ 67 był wyższy w porównaniu do grupy $z$ mikrogruczolakiem $(1,4 \%$ vs $1,03 \%$; $p=0,02)$. Nie stwierdzono zależności pomiędzy indeksem Ki-67, PTTG a progresją guza. W przypadku guzów $z$ dodatnim immunohistochemicznym odczynem w kierunku FSH, indeksy $\mathrm{Ki}$ 67 i PTTG były niższe $(0,6 \%$ vs $1,84 \%$; $p=0,0004$ oraz $0,67 \%$ vs $1,23 \% ; p=0,047$ ). Indeks PTTG był wyższy wśród guzów $z$ pozytywnym odczynem immunohis. tochemicznym w kierunku substancji hormonalnych $(1,2 \%$ vs. $0,1 \% ; p=0,07)$. PTTG był również wyższy w grupie $z$ akromegalią w porównaniu do guzów di. agnozowanych klinicznie jako nieczynne hormonalnie $(1,28 \%$ vs $0,35 \% ; p=0,002)$.

Wnioski: Jądrowa ekspresja Ki-67 i PTTG występowała u większości badanych i wykazywała wzajemna pozytywną korelację. Jedynie większa ekspresja Ki-67 wykazywała znamienny związek $z$ wielkością i cechami inwazyjności guza w badaniu MRI/CT. Nie wykazano związku obu indeksów z progresją guza. 


\section{Introduction}

Pituitary tumours, in majority of cases benign adenomas, account for $10-25 \%$ of intracranial tumours, their prevalence in the general population being $0.02 \%[1,2]$. Anatomically, these tumours are classified as microadenomas (diameter $<1 \mathrm{~cm}$ ) or macroadenomas (diameter $\geq 1 \mathrm{~cm}$ ) $[1,3]$.

Clinically, pituitary tumours may be accompanied by hormonal activity or symptoms of "mass effect", such as invasion of the surrounding tissues (e.g. supra-sellar extension, sinus cavernous invasion and optic nerve compression), causing visual disturbances or headache. Compression of non-tumour pituitary results in varying degrees of hypopituitarism [2]. Based on physical examination and blood hormone levels, pituitary tumours can be broadly classified as either functioning (FPA) or non-functioning pituitary adenomas (NFPA) - comprising approximately $30 \%$ of all adenomas [1]. In about $10 \%$ of autopsies small pituitary adenomas are found, most of them having had no clinical manifestation [3].

The predicted hormonal activity of the tumour is not always confirmed by postoperative immunohistological examination. Within WHO classification (2004) pituitary adenomas are divided according to their hormone secretion as follows: Pit-1 family (prolactinoma, PRL secretion - 50\%; somatotropinoma, $\mathrm{GH}$ secretion - $15-20 \%$; thyrotropinoma, TSH secretion -1\%; plurihormonal adenoma), ACTH family (corticotropinoma - 5-10\%), gonadotropin family (gonadotropinoma, LH, FSH secretion- 1\%), or unclassified adenomas (hormone negative/null cell adenoma, NCA or unusual plurihormonal adenoma) $[2,4,5,6]$.

According to $\mathrm{WHO}$, pituitary tumours are classified according to their morphology features as typical or atypical adenomas (the latter being characterised by invasive growth, increased mitotic index, Ki67 labelling index $>3 \%$ and significant positive p53 nuclear staining) and carcinomas $[4,7,8]$. Pituitary carcinomas are very rare $(0.1$ $0.2 \%$ of all cases of pituitary tumors). They are diagnosed if cerebrospinal or systemic metastases are observed $[1,4,8]$. Most pituitary carcinomas develop from invasive recurrent prolactinomas and corticotropinomas, with very poor prognosis [3]. The therapy of aggressive pituitary tumours and carcinomas is challenging. Besides surgery (sometimes aided by intraoperative low-field MRI), medical treatment, radiotherapy and new cytostatic temozolomide, are used $[9,10]$.

The clinical outcome of pituitary adenomas does not always correlate with the histology of those tumours, some being invasive (30-45\%) and some being clinically aggressive [8]. In invasive adenomas cellular pleomorphism, nuclear atypia, increased cellularity, focal necrosis and mitotic figures are not always present [8]. There are no defined histological criteria to distinguish between benign and malignant tumours, especially between atypical adenomas and pituitary adenocarcinomas.

The inadequacy of WHO's classification of pituitary adenomas and the need to re-examine it is currently under debate
$4,5,8,11,12]$. Trouillas et al. [8] propose a classification of adenomas into non-invasive, non-invasive and proliferative, invasive and non-proliferative and metastatic, while Pasquel et al. [13] suggest that atypical adenomas should be named carcinoma in situ or pre-metastatic cancer.

Typically the term "aggressive" pituitary adenoma is used in clinical practice in the case of a tumour of large size with local mass effect, local invasion, post-operative recurrence, sustained hormonal function despite excision, or resistance to treatment - those being potential indicators of aggressiveness of atypical adenomas [3,7].

The search for a standardized and optimal marker which would consistently correlate with biological tumour behaviour, to enable proper diagnosis, more effective treatment and proper rational post-operative observation, is still under way. Such potential indicators of tumour behaviour are markers of proliferation and angiogenesis. Apart from documented Ki-67 (MIB-1 antibody), topoisomerase II alpha, COX-2, and $\mathrm{Bcl}-2$ were studied $[1,6]$ however, as yet without consistent correlation with tumour invasiveness or recurrence found on MRI or CT [5]. Pawlikowski et al. found prevalent expression of FSHR in invasive and proliferating adenomas as compared with non-invasive and non-proliferating tumours [14]. Pituitary tumour transforming gene (PTTG), vascular endothelial growth factor (VEGF), prothymosin alpha and AIP are new promising markers of biological tumour behaviour.

$\mathrm{Ki}-67$ is a nuclear antigen expressed in G1, S, G2 and M phases of the cell cycle and recognized by the commercially available MIB-1 antibody [15,16]. The Ki-67 labelling index can vary between $<1 \%$ and $23 \%$ [17]. PTTG is an oncogenic protein of the securin family, located on chromosome $5 \mathrm{q} 33$. The function of PTTG is not well known. According to some authors, it can induce fibroblast growth factor (FGF) and vascular endothelial growth factor (VEGF) and inhibits premature sister chromatid separation which is crucial in normal cell mitosis $[2,17]$. Over-expression of PTTG increases cell proliferation and promotes tumour formation in various tissues, such as the thyroid, ovary, breast, prostate, lung, oesophagus, colon and central nervous system $[2,17]$. In pituitary tumours, PTTG appears to be a molecular marker of invasiveness and angiogenesis [17]. The PTTG family is comprised of PTTG1 (the most studied), PTTG2, and PTTG3. In immunocytochemistry PTTG is detected in the nucleus (predominantly) and in the cytoplasm [17].

\section{The aim of this study was:}

1. To determine the usefulness of PTTG as a prognostic factor of pituitary adenoma progression;

2. To evaluate the relationship between the proliferative activity of pituitary adenomas, as quantified by $\mathrm{Ki}-67$ and PTTG indices, and their aggressive biology and clinical data; and,

3. To investigate the correlation between the PTTG labelling index and tumour size and local invasiveness.

\section{Material and methods}

A retrospective analysis was undertaken of clinical records, histopathological and immunohistochemical slides of pituitary adenomas in 55 patients of the Department of Endocrinology, University Hospital in Kraków, who underwent transsphenoidal resection of pituitary adenoma and/or craniotomy in the Department of Neurosurgery, University Hospital in Kraków, between 2003-2012. The diagnosis was established by clinical, biochemical and radiological observations and confirmed by surgery and histopathology. A retrospective analysis of the studied group is presented in table $\mathrm{I}$.

All patients underwent magnetic resonance imaging (MRI) or computed tomography (CT) prior to and one year after surgery, to determine tumour recurrence. Tumour size, defined as its largest dimension, and invasion of neighbouring tissues (destruction of sella turcica, penetration of cavernous sinus, optic chiasm compression, suprasellar propagation), were studied by MR or CT imaging. Tumour invasiveness was defined by radiological criteria $[18,19]$ and from the surgeon's description in the medical records. Tumour progression was evidenced by its recurrence or by increase of the remnant tumour size in MRI/CT.

The surgical specimens were routinely processed, fixed in neutral buffered formalin, embedded in paraffin and placed on slides. In hematoxyline-eosine staining, $18(33 \%)$ of adenomas were acidophilic while $34(62 \%)$ were chromophobic. For immunocytochemistry, sections were incubated, inter alia, with primary mouse monoclonal antibody $\mathrm{Ki}-67$ clone MIB-1 antibody (Dako, M7240, 1:25) and with the primary monoclonal Securin antibody (PTTG, Novocastra, 1:25). To confirm the specificity of the primary antibody, positive and negative control tests were performed, following the manufacturer's instructions.

Ki-67 and PTTG-stained sections were evaluated manually using an optical microscope (Nikon Optishot-2). Ten fields were selected in regions with the highest concentration of positive nuclei and examined at magnification 400x. Each field covered 700 to 3800 cells, depending on the cellularity of the tumour specimen. Ki-67 and PTTG indices were defined as the respective average percentages of positively stained nuclei. Less intensive PTTG immunostaining was also scored in adenoma cell cytoplasm (c-PTTG). In over $90 \%$ of samples with positive nuclear PTTG immunoreactivity, positive c-PTTG immunoreactivity was also observed (Fig. 1).

Statistical analysis (analysis of variance, student's t-test, Pearson's r correlation, Wilcoxon test, Spearman's rank correlation) was performed using the $R$ statistical package (a free software environment for statistical computing and graphics).

This study has been approved by the Local Bioethics Committee of the Jagiellonian University Medical College (certificate KBET/169/B/2010).

\section{Results}

The expression of PTTG and $\mathrm{Ki}-67$ in pituitary adenoma patients, grouped accor- 
Figure 1

Picture 1. 400x magnification. The strong nuclear reaction to PTTG in 2 cells and mixed (nucleartcytoplasmatic) in 1 cell. Picture 2. 400x magnification. The stronger nuclear (in 4 cells) and weaker cytoplasmatic reaction (in the rest of cells) to PTTG.

Obraz 1, powiększenie 400x. Silna reakcja jadrowego PTTG widoczna w dwóch komórkach oraz mieszana (jadrowa I cytoplazmatyczna) widoczna w jednej komórce.

Obraz 2, powiększenie 400x. Silniejsza reakcja jadrowego PTTG widoczna w czterech komórkach oraz slabsza reakcja cytoplazmatycznego PTTG widoczna w pozostalych komórkach.

Table I

Characteristic of the studied group.

Charakterystyka badanej grupy.

\begin{tabular}{|c|c|c|}
\hline \multirow{2}{*}{ General data } & Age, years & $50 \pm 16(21-80)$ \\
\hline & Gender: Female/Male (\%) & $32(58 \%) / 23(42 \%)$ \\
\hline \multirow{5}{*}{ Imaging results } & Largest dimension of tumor [mm] & 100 \\
\hline & Minimal dimension of tumor [mm] & 4 \\
\hline & Microadenoma (\%) / Macroadenoma (\%) & $7(13 \%) / 48(87 \%)$ \\
\hline & Optic chiasm compression (\%) & $28(51 \%)$ \\
\hline & Local invasion of tumor & $43(78 \%)$ \\
\hline \multirow{8}{*}{$\begin{array}{l}\text { Final clinical classification } \\
\text { of pituitary adenomas } \\
\text { in patient group }\end{array}$} & Clinically non-functioning adenoma (NFPA) (\%) & $20(36 \%)$ \\
\hline & prolactinoma (\%) & $2(4 \%)$ \\
\hline & acromegaly (\%) & $31(56 \%)$ \\
\hline & acromegaly + prolactinoma (\%) & $2(4 \%)$ \\
\hline & Cushing disease (\%) & 0 \\
\hline & ganadotropinoma (\%) & 0 \\
\hline & thyrotropinoma (\%) & 0 \\
\hline & silent-ACTH adenoma (\%) & 0 \\
\hline \multirow{9}{*}{$\begin{array}{l}\text { Immunohistochemical } \\
\text { findings }\end{array}$} & Hormonal positivity & $42(78 \%)$ \\
\hline & NCA & $13(22 \%)$ \\
\hline & GH positive & $27(50 \%)$ \\
\hline & PRL positive & $18(33 \%)$ \\
\hline & ACTH positive & $8(15 \%)$ \\
\hline & TSH positive & $6(11 \%)$ \\
\hline & FSH positive & $8(15 \%)$ \\
\hline & LH positive & $11(20 \%)$ \\
\hline & Plurihormonality & $13(24 \%)$ \\
\hline & Histopathological features of malignancy* & $7(13 \%)$ \\
\hline Clinical observation after $1 \mathrm{y}$ & Progression & $16(29 \%)$ \\
\hline
\end{tabular}

"Classic histopathological features of malignancy, like nuclear polymorphism, presence of mitotic figures, high cellularity, cytological atypia, presence of necrosis might be an indicator of more aggressive behavior.

*Klasyczne histopatologiczne cechy zlośliwości, takie jak polimorizm jadrowy, obecność figur milotycznych, znaczna liczba komórek, cytologiczna atypia, obecność zmian nekrotycznych, mogą być wskaźnikami zwiększonej agresywności guza.

\section{Table II}

Ki-67 and PTTG expression in the studied group.

Ekspresja Ki-67 I PTTG w badanej grupie.

\begin{tabular}{|c|c|c|c|}
\hline \multirow{2}{*}{ Frequency } & Ki-67 & PTTG & - value \\
\cline { 2 - 4 } & $88 \%$ & $85 \%$ & \\
\hline $\begin{array}{c}\text { Median } \\
\text { index [\%] }\end{array}$ & $1,4 \%$ & $1,0 \%$ & $p=0,006$ \\
\hline
\end{tabular}

ding to their final diagnosis (acromegaly, prolactinoma, NFPA) is shown in figure 2. The values of studied indices are shown in the table II.

Progression of the tumour within 12 months of the observation was found in 16 cases $(29 \%)$. However, we did not find any significant difference between median Ki-67 index in tumours with and without progression $(1.65 \%$ vs. $1.22 \% ; p=0.896)$. Similarly there was no significant difference between median PTTG index in tumours with and without progression $(0.97 \%$ vs. $1.12 \%$; $\mathrm{p}=0.82$ )

PTTG and $\mathrm{Ki}-67$ expression were correlated (rho $=0.37 ; p=0.006$ ), as illustrated in figure 3.

The group with macroadenoma consisted of $48(87 \%)$ patients. In comparison to the group with microadenoma $(n=7) \mathrm{Ki}-67$ expression was higher (1.4\% vs. $1.03 \%$; $p=0.019$ ) (Fig. 4).

In patients with macroadenoma, no correlation between Ki-67 or PTTG and local invasion, tumor size and progression was found.

The Ki-67 index was significantly higher in locally invasive tumors ( $1.39 \%$ vs. $0.64 \%$; $p=0.034$ ). No relationship between optic chiasm destruction and Ki-67 or PTTG expression was found.

PTTG index was significantly higher in patients with positive immunohistochemical hormonal expression $(1.2 \%$ vs. $0.1 \%$; $p=0.07$ ) in comparison to NCA, while in case of $\mathrm{Ki}-67$ there was no relationship. However, median $\mathrm{Ki}-67$ and PTTG indices were higher in patients with negative expression towards FSH than with positive expression towards FSH $(1.84 \%$ and $1.23 \%$ versus $0.6 \%$ and $0.67 \%$ respectively; $p=0.0004$ and $p=0.047$ respectively).

In a group of patients with positive expression of $\mathrm{GH}$, local invasion was more often found than in the group with negative expression towards $\mathrm{GH}(\mathrm{p}=0.002)$.

According to their clinical diagnosis we divided patients into two main groups: with acromegaly and NFPA ( $n=31,56 \%$ and $n=20,36 \%$ ) respectively). There was significant difference in median PTTG between those groups; acromegaly $-1.28 \%$ and NFPA $-0.35 \% ; p=0.002$ (Fig. 2,5).

All NFPA patients presented local invasion. There was a significant difference in local invasion frequency between those groups: with acromegaly - $19(61 \%)$, with NFPA 20 (100\%); $p=0.004$ (Tab. IV).

We found correlation between PTTG expression and age. PTTG index was considerably higher in younger patients $(p=0.0019)$. Whereas, Ki-67 index was higher in women $(p=0.039)$.

Cytoplasmic PTTG (c-PTTG) expression was not related to the invasiveness nor hormonal activity of examined tumours.

\section{Discussion}

Our study contributes to the on-going search for a new biological marker useful in early diagnosis of pituitary adenoma and carcinoma. So far, no marker to independently predict aggressive behaviour of such tumours has been found. Correlation between $\mathrm{Ki}-67$ and tumours recurrence was observed in several studies $[8,20,21]$. The statistically significant correlation between $\mathrm{Ki}-67$ index and tumour size and invasiveness (higher in macroadenomas) found in our study agrees with some of these observations $[11,21]$. However, in agreement with other studies $[22,23,24]$, we were not able to correlate tumour progression with the Ki-67 index. 


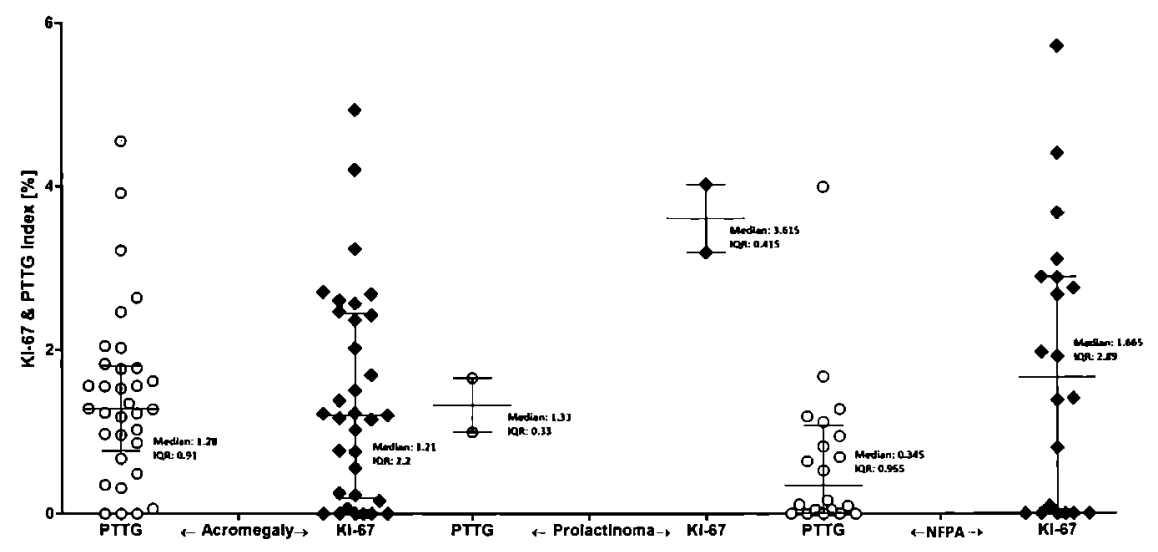

Figure 2

Expression of PTTG and Ki-67 in patients with pituitary adenoma grouped according to their final diagnosis. Ekspresja PTTG oraz Ki-67 u pacjenlów z gruczolakiem przysadki w zależności od oslatecznego rozpoznania.

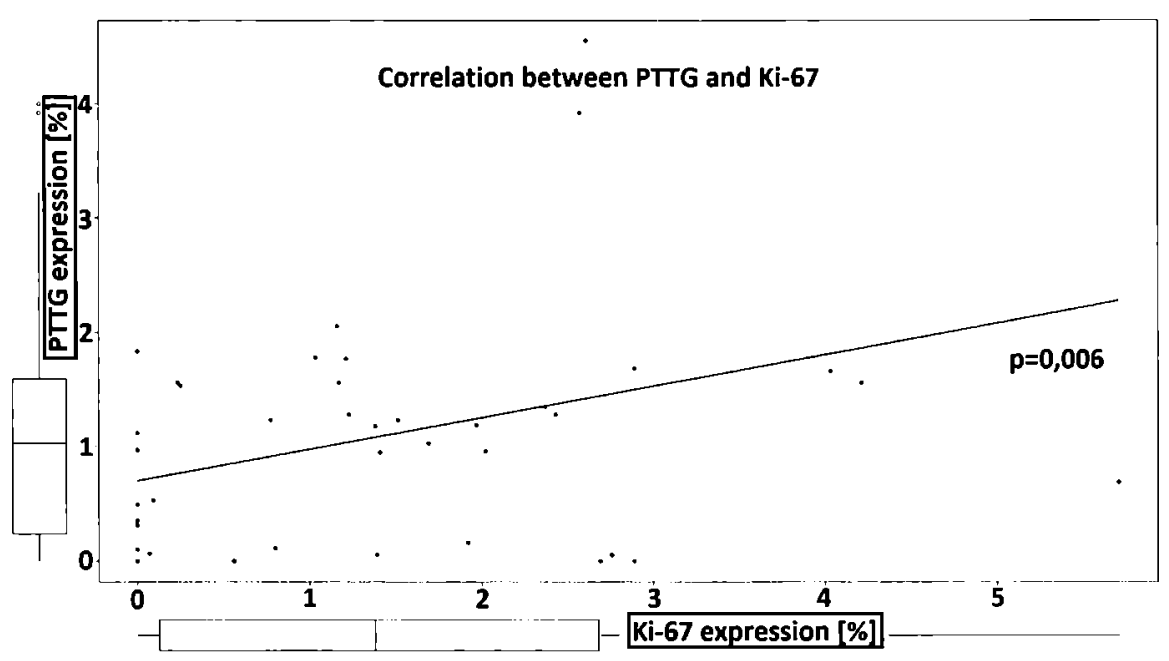

Figure 3

Correlation between PTTG and Ki-67 indices.

Korelacja indeksów PTTG oraz Ki-67.

Table III

Histopathological features and radiological progression (after 1 year of observation) of patients with or without local invasion found on MRICT.

Obraz histopatologiczny oraz progresja w badaniach obrazowych (po 1 roku obserwacji) u pacjentów z obecna oraz nieobecną miejscową inwazyjnościa guza w badaniu MRI/CT.

\begin{tabular}{|c|c|c|c|c|}
\hline & & $\begin{array}{c}\text { No invasion } \\
(n=12,22 \%)\end{array}$ & $\begin{array}{c}\text { Invasion } \\
(n=43,78 \%)\end{array}$ & $p$-value \\
\hline Tumor progression on MRI/CT & & $2(16,6 \%)$ & $14(32 \%)$ & $p=0,47$ \\
\hline $\begin{array}{c}\text { Histopathological markers } \\
\text { of proliferation }\end{array}$ & Ki-67 & $0.64 \%$ & $1.39 \%$ & $p=0,034$ \\
\hline $\begin{array}{c}\text { Histopathological indicators } \\
\text { of aggressiveness }\end{array}$ & PTTG & $1.0 \%$ & $1.12 \%$ & $p=0.75$ \\
\hline
\end{tabular}

\section{Table IV}

Histopathological and MRI/CT findings (after 1 year of observation) of patients with acromegaly and NFPA (non-functioning pituitary adenomas).

Wyniki badania histopatologicznego oraz obrazowego (po 1 roku obserwacji) u pacjentów z akromegalia oraz NFPA.

\begin{tabular}{|c|c|c|c|c|}
\hline & & $\begin{array}{c}\text { Acromegaly } \\
(\mathbf{n}=31,56 \%)\end{array}$ & $\begin{array}{c}\text { NFPA } \\
(\mathbf{n}=20,36 \%)\end{array}$ & p-value \\
\hline & Local invasion & $19(61 \%)$ & $20(100 \%)$ & $\mathbf{0 . 0 0 1}$ \\
\hline MRI/CT findings & Tumor progression & $9(29 \%)$ & $6(30 \%)$ & 1 \\
\hline \multirow{2}{*}{ Histopathological markers of proliferation } & Ki-67 & 1.21 & 1.67 & 0.4 \\
\cline { 2 - 5 } & PTTG & 1.28 & 0.35 & $\mathbf{0 . 0 0 2}$ \\
\hline Histopathological indicators of aggressiveness & & $6(19 \%)$ & $1(5 \%)$ & 0.22 \\
\hline
\end{tabular}

We note the limited number of studies concerning PTTG expression in pituitary tumours.

PTTG and pituitary adenoma progression

Filippella et al. [25] studied the expression of PTTG and Ki-67 in 45 pituitary adenomas reporting correlation between PTTG and $\mathrm{Ki}-67$ and their both cut-off value which could predict recurrence was $2.9 \%$.

A similar study, but concerning NFPA only, was reported by Noh et al [26], who investigated 35 pituitary adenomas finding correlation between $\mathrm{Ki}-67$ and PTTG expression with tumor recurrence. We found a statistically significant relationship between PTTG and Ki-67 expression, but no relevant association among PTTG and tumour progression or tumour size, in agreement with other studies $[22,23,24,27]$.

PTTG, local invasiveness and recurrence

It is generally accepted, and also supported by our study, that invasive adenomas have a higher proliferation rate and $\mathrm{Ki}-67$ indices. In a study of correlation between PTTG and local invasion Sanches-Tejada et al. [22] using a sensitive real-time reverse transcriptase polymer chain reaction (RT-PCR) assay, detected PTTG in their samples, finding PTTG expression to be lower in invasive than in non-invasive tumours, however not being significantly correlated with tumour recurrence.

Wierinckx et al. [23], who examined PTTG in prolactinomas only, found no correlation between PTTG and clinical course (invasiveness and recurrence). While their findings are somewhat similar to ours, in that we were not able to find a correlation between PTTG index and tumour recurrence or invasiveness. Although, we noted a higher PTTG expression in acromegalic patients than in NFPA, it was the group with NFPA which had a higher rate of invasiveness.

\section{PTTG and hormonal activity}

Hunter et al. [28] using techniques based on RT-PCR, showed that levels of PTTG mRNA in somatotropinomas were significantly higher than those in NFPA [28]. Also Zhang et al. [29] evaluated the expression of PTTG with RT-PCR in 54 pituitary adenomas and in normal pituitary tissue, finding that PTTG over-expression correlated with tumour invasiveness in FPA (which had invaded the sphenoid bone). Although results of $\mathrm{McC}$ abe et al. [24] contradicted those of Zhang et al. [29] (higher PTTG mRNA in NFPA), our study supports a positive correlation between the PTTG and FPA and PTTG and somatotropinomas.

Ramirez and al. [27] analyzed NFPA in 74 patients (average $\mathrm{Ki}-67$ index value of $1.49 \%$ ), in whom significant dependence of this index on tumor size (higher indices at tumour size $>30 \mathrm{~mm}$ ) and tumour recurrence were observed. They did not find such correlation with respect to PTTG [27]. In our study, the group with NFPA consisted of 20 samples and the median $\mathrm{Ki}-67$ index was $1.67 \%$. However, among NFPA we did not prove any correlation in between $\mathrm{Ki}-67$ or PTTG and tumour size $>30 \mathrm{~mm}$. 


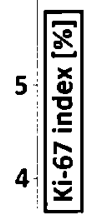

3

Median: 1.03

IQR: 1.425

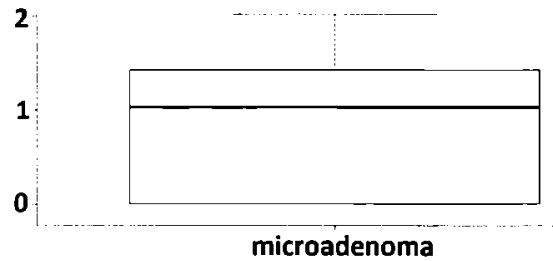

Figure 4

Distribution of Ki-67 index in patients with microadenoma and macroadenoma.

Rozklad indeksu Ki-67 u pacjentów z mikrogruczolakiem i makrogruczolakiem.

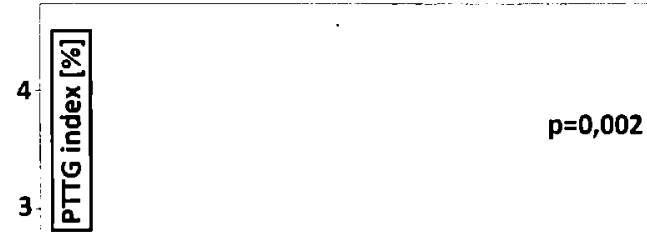

2

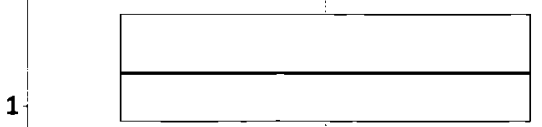

Mean: 1.4

Median: 1.28

O IQR: 0.91

acromegaly

NFPA

Figure 5

Distribution of PPTG index in patients with acromegaly and NFPA.

Rozklad indeksu PTTG u pacjentów z akromegalia oraz NFPA.

\section{PTTG and macroadenoma}

Jia et al.[30] investigated the relationship between PTTG and invasiveness in 70 patients with macroadenomas and using RT-PCR demonstrated positive correlation between PTTG and local invasion. In our study of 48 patients with macroadenoma we did not find such a relationship.

We are aware of the relatively short follow up and the small and heterogeneous group of analysed tumours as the limitations of our study.

While PTTG and Ki-67 appear to play an important role in pituitary tumorigenesis there is no consensus as to the distinction between benign and aggressive pituitary adenomas. The limitations of PTTG and $\mathrm{Ki}-67$ as markers are probably connected with their multiple cellular functions. Prospective exploration of proliferative markers in recurrent and invasive pituitary adenomas could lead to effective targeted therapy of these tumours.

\section{Conclusions}

1. Expression of $\mathrm{Ki}-67$ and PTTG was observed in the majority $(88 \%$ and $85 \%$
Median: 1.4

IQR: $\mathbf{2 . 5 1}$

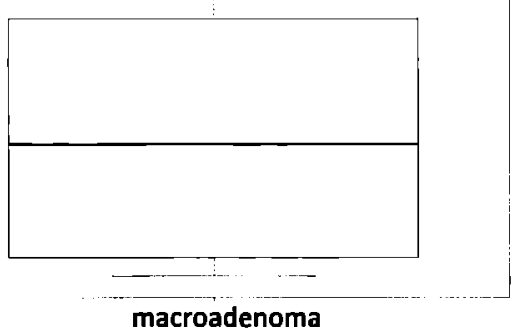

macroadenoma
Registry. Eur J Endocrinol. 2007; 156: 203-216.

4. Oktar N: Controversies and innovations in the new WHO classification of pituitary adenomas. J Neurol Sci (Turkish) 2006; 23: 68-69.

5. Al-Shraim M, Asa SL: The 2004 World Health Organization classification of pituitary lumours: what is new? Acta Neuropathol. 2006; 111: 1-7.

6. Bałdys-Waligórska A, Krzentowska A, Golkowski F, Sokolowski G, Hubalewska-Dydejczyk A: The prevalence of benign and malignant neoplasms in acromegalic patients. Endokrynol Pol. 2010; 61: 29-34.

7. Sokolowski G, Baldys-Waligórska A, Trofimiuk $M$, Adamek D, Hubalewska-Dydejczyk $A$. et al: Expression of cyclooxygenase-2 (COX-2) in pituitary tumours. Med Sci Monit. 2012; 18: 252-259.

8. Trouillas J, Roy P, Sturm N, Dantony E, Cortet-Rudelli C. et al: Anew prognostic clinicopathological classification of pituitary adenomas: a multicentric case-control study of 410 patients with 8 years post-operative follow-up. Acta Neuropathol. 2013; 126: 123-135.

9. Tabakow $P, C z y z M$, Jarmundowicz $W$, Lechowicz-Glogowska E: Surgical treatment of pituitary adenomas using low-field intraoperative magnetic resonance imaging. Adv Clin Exp Med. 2012; 21; 495-503.

10. Ortiz LD, Syro LV, Scheithauer BW: Temozolomide in aggressive piluitary adenomas and carcinomas. Clinics (Sao Paulo) 2012; 67: 119-123.

11. Zada G, Woodmansee WW, Ramkissoon S, Amadio J, Nose V. et al: Atypical pituitary adenomas: incidence, clinical characleristics, and implications. J Neurosurg. 2011; 114: 336-344.

12. Mete O, Ezzat S, Asa S: Biomarkers of aggressive pituitary adenomas. J Mol Endocrinol. 2012; 49:69-78.

13. Pasquel FJ, Vincenti C, Brat DJ, Oyesiku NM, loachimescu AG: Pituitary carcinoma in situ. Endocr Pract. 2013; 19: 69-73.

Mean: 0.67

Median: 0.345 IQR: 0.955

14. Pawlikowski M, Radek M, Jaranowska M, Kunert-Radek J, Świętoslawski J, Winczyk K: Expression of follicle stimulating hormone receptors in pituitary adenomas - a markes of tumour aggressiveness? Endokrynol Pol. 2014: 65: 469-471.

15. Mastronardi L, Guiducci A, Puzzilli F: Lack of correlation between $\mathrm{Ki}-67$ labelling index and tumour size of anterior pituitary adenomas. BMC Cancer 2001; 1:12.

16. Botelho CH, Magalhães AV, Mello PA, Schmitt FC, Casulari LA: Expression of p53, Ki-67 and c-erb B2 in growth hormone-and/or prolactin-secreting piluitary adenomas. Arq Neuropsiquiatr. 2006; 64: 60-66.

17. Salehi F, Kovacs K, Scheithauer BW, Lloyd RV, Cusimano M: Pituitary tumour-transforming gene in endocrine and other neoplasms: a review and update. Endocr Relat Cancer 2008; 15: 721-743.

18. Knosp E, Steiner E, Kitz K, Matula C: Piluitary adenomas with invasion of the cavernous sinus space: $A$ magnetic resonance imaging classification compared with surgical findings. Neurosur.1993; 33: 610-618.

19. Zada G, Lin N, Laws ER: Patterns of extrasellar extension in growth hormone-secreting and nonfunctional pituitary macroadenomas. Nerosurg Focus 2010; 29: 1-5.

20. Daita G, Yonemasu Y: Dural invasion and proliferative potential of pituilary adenomas. Neurol Med Chir (Tokyo) 1996; 36: 211-214.

21. Thapar K, Kovacs K, Stefaneanu L, Scheithauer $B$, Killinger DW. et al: Overexpression of the growth-hormone-releasing hormone gene in acromegaly-associated pituitary tumours. An event associated with neoplastic progression and aggressive behavior. Am J Pathol. 1997: 151: 769-784.

22. Losa M, Barzaghi RL, Mortini P, Franzin A, Mangili $F$. et al: Determination of the proliferation and apoplotic index in adrenocorticotropin-secreting pituitary tumours : comparison between micro- and macroadenomas. Am J Pathol. 2000; 156: 245-251.

23. Sánchez-Tejada L, Sánchez-Ortiga R, Moreno-Pérez O, Montañana CF, Niveiro M. et al: Pituitary tumour transforming gene and insulin-like growth factor 1 receptor expression and immunohistochemical measurement of Ki-67 as potential prognostic markers of pituilary lumours aggressiveness. Endocrinol Nutr. 2013; 60: 358-367.

24. Wierinckx $A$, Auger $C$, Devauchelle $P$, Reynaud A, Chevallier P. et al: A diagnostic marker set for invasion, proliferation, and aggressiveness of 
prolactin pituitary tumours. Endocr Relat Cancer 2007; 14: 887-900.

25. McCabe CJ, Khaira JS, Boelaert K, Heaney AP, Tannahill LA. et al: Expression of pituitary tumour transforming gene (PTTG) and fibroblast growth factor-2 (FGF-2) in human pituitary adenomas: relationships to clinical tumour behaviour. Clin Endocrinol (Oxf) 2003; 58: 141-150.

26. Filippella $M$, Galland $F$, Kujas M, Faggiano A Lombardi G. et al: Pituitary tumour transforming gene (PTTG) expression correlates with the proliferative activity and recurrence status of pituitary adenomas: a clinical and immunohistochemical study. Clin Endocrinol (Oxf) 2006; 65: 536-543.

27. Noh TW, Jeong HJ, Lee MK, Kim TS, Kim SH, et al: Predicting recurrence of nonfunctioning pituitary adenomas. J Clin Endocrinol Metab. 2009; 94: 4406-4413

28. Ramirez C, Cheng S, Vargas G, Asa SL, Ezzat S. et al: Expression of Ki-67, PTTG1, FGFR4, and SSTR2, 3 , and 5 in nonfunctioning pituitary adenomas: a high throughput TMA, immunohistochemical study. J Clin Endocrinol Metab. 2012; 97: 1745-1751.

29. Hunter JA, Skelly RH, Aylwin SJ, Geddes JF,
Evanson J. et al: The relationship between pituitary tumour transforming gene (PTT) expression and in vitro hormone and vascular endothelial growth factor (VEGF) secretion from human pituitary adenomas. Eur J Endocrinol. 2003; 148: 203-211.

30. Zhang X, Horwitz GA, Heaney AP, Nakashima $M$, Prezant TR. et al: Pituilary tumour transforming gene (PTTG) expression in pituitary adenomas. J Clin Endocrinol Metab. 1999; 84: 761-767.

31. Jia W, Lu R, Jia G, Ni M, Xu Z: Expression of pituitary tumour transforming gene (PTTG) in human pituitary macroadenomas. Tumour Biol. 2013; 34: 1559-1567. 